\title{
Linguistic securitisation as a governmentality in the neoliberalising welfare state
}

Kraft, Kamilla

Published in:

Language, Governmentality and Neoliberalism

DOI:

$10.4324 / 9780429286711-2$

Publication date:

2019

Document version

Peer reviewed version

Document license:

Unspecified

Citation for published version (APA):

Kraft, K. (2019). Linguistic securitisation as a governmentality in the neoliberalising welfare state. In L. Martín Rojo, \& A. Del Percio (Eds.), Language, Governmentality and Neoliberalism (pp. 29-48). Routledge. Language, Society and Political Economy https://doi.org/10.4324/9780429286711-2 
REFERENCE: Kraft, Kamilla. 2019. Linguistic securitisation as a governmentality in the neoliberalising welfare state. In: Luisa Martín Rojo and Alfonso Del Percio. Language and Neoliberal Governmentality, 29-48. London/New York: Routledge.

DOI: $10.4324 / 9780429286711-2$

\section{Linguistic Securitisation as a Governmentality in the Neoliberalising}

\section{Welfare State}

\subsection{Introduction: A Neoliberal Industry in a Welfare State}

In the Nordic welfare states - Denmark, Finland, Iceland, Norway and Sweden - neoliberal logics are often understood as being in stark political contrast to the traditional welfare state logics of these countries. A major point of this ideological conflict is employment liberalisation (Peck, Theodore, \& Ward, 2005), especially employee leasing which refers to the practice of companies hiring staff on a day-to-day basis from staffing agencies. This conflict is waged between left-wing and right-wing politicians, but is also significant for trade unions as well as employer and business organisations that hold significant influence in the Nordic welfare state model (Gösta EspingAndersen, 1990). By opponents, employee leasing is seen as a trademark of neoliberalism, linked to growing deregulation and flexibilisation of labour. Such processes have been described by Richard Sennett (1998) as characteristic of a new form of capitalism and by Nancy Fraser (2003) as a postFordist governmentality. The critique of flexibilisation and employment liberalisation is first and foremost that risks which used to affect companies are now instead redistributed to the employees. For example, should a company experience decreased productivity or be under financial pressure, management can fire employees with no or highly limited notice to decrease costs. This is part of the business model known as 'just-in-time' or 'lean' production which aims to increase profit by reducing costs (Kotler, 2003, p. 226), including employee costs. Proponents understand this flexibility as an essential means of ensuring that companies can survive and profit in a market dominated by steep competition.

The construction industry is a central object of this struggle since it is one of the most deregulated areas of the labour market. It is also an industry which relies heavily on employee leasing. The Norwegian construction industry, which will be the object of analysis in this chapter, is the largest area by far in the staffing industry; $32 \%$ of all workers in staffing agencies are being leased as builders by contractors (NHO, 2016). A substantial part of the leased workers is from Poland, 
REFERENCE: Kraft, Kamilla. 2019. Linguistic securitisation as a governmentality in the neoliberalising welfare state. In: Luisa Martín Rojo and Alfonso Del Percio. Language and Neoliberal Governmentality, 29-48. London/New York: Routledge.

DOI: 10.4324/9780429286711-2

currently constituting the biggest group of work migrants in Norway1. Norwegian work sociologists explain this as an outcome of two interrelated processes (Friberg, 2016). In 2004, Poland joined the European Union which Norway had been collaborating with as a member of the European Free Trade Association (EFTA) since 1994. This meant that work migration from Poland to Norway, in addition to work migration from the other Nordic countries with which Norway had had free mobility agreements since 1954, increased significantly (Friberg \& Eldring, 2013; Friberg \& Golden, 2014). The 2004 EU expansion coincided with a deregulation of the Norwegian labour market in 2000, which had made employee leasing legal in all areas of the labour market (Alsos, Bråten, \& Trygstad, 2016; Ødegård \& Andersen, 2011). This resulted in a situation where staffing companies got easy access to a labour force of mobile workers from Poland, who in turn got access to work or to better paid work.

Attacks on employee leasing - often spearheaded by trade unions and left-wing politicians - are frequent and emphasise how leased workers are economically disadvantaged compared to their permanently employed colleagues, how they have fewer rights and worse employment conditions, and also how they are more vulnerable in terms of accidents (cf. e.g. Prestegård (2015) and Bals (2017)). One of the most frequent critiques of leasing is related to the latter point, namely safety. The construction industry tops the annual statistics for fatal and severe accidents (Arbeidstilsynet, 2017; Byggeindustrien, 2014a, 2015) and hence security and safety become weighty arguments for regulation aimed at securitisation. Not surprising then, both employer and employee organisations commit themselves to the common cause of ensuring safety and security for both Norwegian and migrant workers. Especially the latter group has received considerable attention since the Norwegian Labour Inspection Authority as well as industry stakeholders have identified these workers as particularly exposed to risks (Arbeidstilsynet, 2012; Byggeindustrien, 2014b).

Studies from the European Agency for Safety and Health at Work as well as reports from the Norwegian Labour Inspection Authority (Arbeidstilsynet, 2012) identify various causes for accidents at work: Long work hours, high-risk industry and high-risk tasks, different cultures, language and communication, as well as employee leasing which entails that workers often do not have the time to acquire enough knowledge about safety procedures in the various workplaces to

\footnotetext{
1 https://www.imdi.no/om-integrering-i-norge/innvandrere-og-integrering/innvandrerbefolkningen-i-norge/ (accessed September 17 2018)
} 
REFERENCE: Kraft, Kamilla. 2019. Linguistic securitisation as a governmentality in the neoliberalising welfare state. In: Luisa Martín Rojo and Alfonso Del Percio. Language and Neoliberal Governmentality, 29-48. London/New York: Routledge.

DOI: 10.4324/9780429286711-2

which they are sent. These reasons, however, are not emphasised equally in the process of making the industry safer and more secure. While the above-mentioned studies have identified employee leasing as one, if not the biggest, cause of accidents amongst migrant workers, language and communication often feature more prominently in safety and security debates and initiatives. This contributes to leasing, the very core of the industry's flexibility, becoming less visible within securitisation debates. Hence, the practice can remain relatively uncontested, and maintain its status as an inevitable part of the construction industry. Meanwhile, the focus on language and communication as part of ensuring safe workplaces and work conditions for all shows commitment to conducting business under flexible, yet safe conditions.

The aim of this chapter is to analyse how, why and with what consequences language and communication are constructed as conditions for the securitisation of flexible labour in the Norwegian construction industry. It will also discuss the management and control of workers and work. Conceptually, the analysis will draw on Michel Foucault's concepts of 'governmentality' and 'technology of power' in particular. These will allow for a demonstration of how institutions and agents through various practices, rationalities and techniques (re)produce a system of governance based on security in the construction industry. This governance is not coercive, rather it shapes conditions that require companies and workers to internalise practices and logics to uphold constant securitisation. This 'governmentality' and especially its 'technologies of power', such as securitisation procedures, analyses and reflections, shape the conduct of workers and make them act in ways that are beneficial to themselves as well as to society at large (Foucault, 1988, 1991). Foucault's concept of governmentality, i.e. management of populations, underscores power as multi-centric and productive; it produces specific logics, which become the basis of interventions, social relations, subjectivities, as well as material objects. Moreover, this process takes place on different levels, in different context, and with different agents.

To conduct this analysis, I will draw on ethnographic data generated between 2014 and 2018 in Norwegian construction sites. The data set consists of fieldnotes from observations and conversations, video-recorded interactions of employees' and managers' daily work, recorded interviews, and various materials, including legal documents and news articles, on safety and security. Such a broad data set is an advantage when dealing with studies of governmentality, since such studies must provide an understanding of both government and mentality, i.e. insights into 
REFERENCE: Kraft, Kamilla. 2019. Linguistic securitisation as a governmentality in the neoliberalising welfare state. In: Luisa Martín Rojo and Alfonso Del Percio. Language and Neoliberal Governmentality, 29-48. London/New York: Routledge.

DOI: $10.4324 / 9780429286711-2$

institutional as well as individuals' logics. Different methodologies are used in the analysis of these data, including interactional sociolinguistics for the recordings (Goffman, 1983; Gumperz \& CookGumperz, 2012; Rampton, 2014) and text and multimodal analysis (Kress \& Van Leeuwen, 2001; Skovholt \& Veum, 2014) for the written texts.

This chapter will be ordered in the following way: Section 2.0 engages with theories of neoliberal and welfarist governmentality, flexibilisation, and securitisation. This theoretical outline will demonstrate, 1) how the logics of both welfarism and neoliberalism have been part of forming government, and 2) how these logics are invested in the macro level of policies as well as the micro level of individuals' orientations and common sense. In section 3.0 the analysis is presented in three sub-sections to show construction, circulation and consequences of the language, safety and security discourse. Section 4.0 discusses how certain logics about safety and language become a system of governing logics - a governmentality - that may provide for the co-existence of a welfare state and a neoliberalising labour market.

\subsection{Welfarism, neoliberalism, securitisation}

Since the early 1900s, welfarism has been a dominant political rationality that has governed labour and society in Norway. Based on a utilitarian idea about the well-being of the collective, welfarism operates through a social contract between the state and the individual. The state has to provide socio-economic welfare and stability, while citizens in return have to work and provide the state with income through taxes. In Norway, welfare benefits are considered universal, i.e. all citizens are entitled to them. This is based on a political rationale of decommodification of welfare. This decommodification is ensured through active labour market policies aiming at full employment and a coordinated market economy, making the regulations of the labour market and social insurance policies "core areas of welfare policy" (Larsson et al. 2012: 4). Larsson et al. (2012) argue that the Nordic welfare model has been designed as a governmentality that ensures maximum compromise and minimal conflict between state, business and labour as well as low levels of government coercion. Accordingly, the labour market has historically been regulated by tripartite negotiations between government, business (represented by employer organisations) and labour (represented by trade unions) (Gosta Esping-Andersen, 1999; Gösta Esping-Andersen, 1990; Gallie, 2007). 
REFERENCE: Kraft, Kamilla. 2019. Linguistic securitisation as a governmentality in the neoliberalising welfare state. In: Luisa Martín Rojo and Alfonso Del Percio. Language and Neoliberal Governmentality, 29-48. London/New York: Routledge.

DOI: 10.4324/9780429286711-2

Welfarism is often considered the contrast to neoliberalism as this ideology aims at minimal state intervention, deregulation of markets, and individual responsibility. Its philosophical foundation is liberalism, strongly emphasising individual freedom and choice. Neoliberal supporters have criticised welfarism as a form of governance that makes citizens dependent on the state. Thus, neoliberalism can be summed up as a governmentality that argues in favour of free, self-regulating markets and individuals who are themselves responsible for their choices and trajectories (Harvey, 2005; Willig, 2009).

While increasing deregulation and flexibilisation may be understood as signs of the dwindling influence of the welfare state and of take-over by a neoliberal system, scholars investigating the history of the Nordic welfare states (Larsson et al. 2012) argue that the welfare states are at most neoliberalising, since they maintain clear welfare state logics too. The authors' point is that the Nordic welfare states have moved from strict social control of the population aimed at ensuring a utilitarian aim of what is best for most, to increasing individualisation. However, they also underscore that the waxing and waning of welfarism and neoliberalism is a historically on-going process. This is in line with Rose et al.'s (2006) argument that the so-called neoliberal mode of government is not a contrast to, but rather a continuation of the welfare states that characterised Europe and North America after the Second World War. They suggest that a more accurate understanding would be to view liberalism, welfarism and what they call advanced liberalism, rather than neoliberalism, as historical continuities, which implies that contemporary modes of government contain traces of all these ideologies. The transformations of states may be in pursuit of neoliberal logics, but these co-exist with logics of welfarism and liberalism.

An example of a process where neoliberal and welfare logics struggle and combine is what is often described as the shift from welfare to workfare. This shift was initiated with the labour parties' 'third way' which included more privatisation and deregulation of markets (Larsson et al. 2009:8), and challenged the principle of universalism, yet without dismantling the Nordic welfare model (Torfing, 2009). Increased flexibilisation of work and the workforce is changing the stability of livelihoods in the universal welfare states. Still, flexibilisation and stability, represented e.g. by temporary contracts and permanent appointments respectively, both operate in the labour market. Yet, in the construction industry they predominately target different groups of workers, namely "migrants" and "locals" respectively (Friberg \& Haakestad, 2015). 
REFERENCE: Kraft, Kamilla. 2019. Linguistic securitisation as a governmentality in the neoliberalising welfare state. In: Luisa Martín Rojo and Alfonso Del Percio. Language and Neoliberal Governmentality, 29-48. London/New York: Routledge.

DOI: $10.4324 / 9780429286711-2$

As described in the introduction, flexibilisation, especially employee leasing, has been criticised for being connected to safety risks. The combination of the industry's reliance on employee leasing and the critique of this practice as risk-inducing has led to a situation where safety and security can legitimise the regulation of the construction industry. On the one hand, regulations may satisfy welfarist demands about taking responsibility for the well-being of all, also in a deregulated and flexibilised labour market and industry. On the other hand, safety and security regulations become a justification of the continued use of neoliberal flexibilisation practices. In this way these two logics combine to create a governmentality of securitisation.

Securitisation has been studied as a tool used by the state to control its population, especially under globalising conditions. In securitisation and migration studies it has been argued that securitisation allows for enforcing restrictions on one's own and other countries' populations, particularly the latter, at the same time as states can engage in global mobility and the global economy (Lazaridis \& Wadia, 2015). Charalambous et al. (2015) argue that securitisation is an "institutional process" which incorporates regulations so as to avoid threats to the "existence of the state and other bodies [...]. Throughout this process, discourse plays a crucial part, both in declaring a particular group, phenomenon or process to be an existential threat, and in persuading people that this warrants the introduction of special measures" (Charalambous et al., 2015, p. 2). To take such measures necessitates the identification of risk groups and processes, and subsequently the introduction of regulations.

\subsection{Securitisation through language}

\subsection{The discursive construction of language as part of securitisation}

In order to argue that discourses on language and securitisation become a technology of the management of risk, the first aim of this analysis is to demonstrate how language and the communicative competence of specific workers are discursively constructed as interlinked with questions of safety and security in the construction site. Organisations that represent the (supra)national level as well as organisations that represent the industry both take part of this construction. I will begin by analysing the former. 
REFERENCE: Kraft, Kamilla. 2019. Linguistic securitisation as a governmentality in the neoliberalising welfare state. In: Luisa Martín Rojo and Alfonso Del Percio. Language and Neoliberal Governmentality, 29-48. London/New York: Routledge.

DOI: $10.4324 / 9780429286711-2$

The Norwegian Labour Inspection Authority is the principle institution concerned with matters of safety and security in Norwegian workplaces. It is a governmental agency under the Ministry of Labour and Social Affairs2. The institution has to ensure that employers uphold the legislation on Health, Work Environment, Safety and Security (HESS) in their workplaces. Furthermore, it disseminates HESS legislation, evaluates HESS practices in workplaces, and makes recommendations for new standards 3 . This particular institution is, in other words, a crucial part of enforcing government power.

The English version of the Labour Inspection Authority's website, under the header "Safety and Health", looks like this:

\section{Arbeidstilsynet}

\section{Safety and Health}

Foreign workers have a higher risk of work accidents than their Norwegian colleagues. Workers in the industry and construction sector are exposed to the highest risk, regardless of nationality.

The reasons why foreign workers have a higher risk of work accidents are many and complex. The reasons are for instance: language barriers, that they more often are employed in sectors with high risks, many are hired labor and therefore not an integrated part of the safety culture at the work place. Foreign workers often work long hours, which might be another risk factor.

"Foreign workers", the majority of whom are leased workers, is the first category that is activated in this text. Moreover, construction workers in general, but especially "foreign" workers, are assessed as being at risk. The list of reasons for this is long, and "language barriers" features prominently as the first point. That they are "hired labour", i.e. leased, is also mentioned though with the causal

2 From arbeidstilsynet.no, English version https://www.arbeidstilsynet.no/en/about-us/ (accessed August 22nd 2018)

${ }^{3}$ From arbeidstilsynet.no, Norwegian version https://www.arbeidstilsynet.no/om-oss/ (accessed August 22nd 2018) 
REFERENCE: Kraft, Kamilla. 2019. Linguistic securitisation as a governmentality in the neoliberalising welfare state. In: Luisa Martín Rojo and Alfonso Del Percio. Language and Neoliberal Governmentality, 29-48. London/New York: Routledge.

DOI: $10.4324 / 9780429286711-2$

conjunction that they do not become part of "the safety culture at the work place", i.e. it is explicitly mentioned that the issue is not the practice of employee leasing in and of itself. This point is the only item on the list that is not presented as self-explanatory as to why "foreign workers" labour under more risk. In contrast, "language barriers" is a point that is not modified, nor explained.

Interestingly, the Norwegian website looks rather different. While language also appears here under the Safety and Health section, it is much further into the text, and it is simply one point on one out of three lists explicating different risk factors in construction sites. "Språk- og kommunikasjonsproblemer" [Language and communication problems] is mentioned as the ninth reason out of ten as to why so-called 'unwanted situations' may occur4. Arguably, the focus on "foreign workers" and the role of language and communication seem to be emphasised in the version of the website which is arguably addressed to "foreign" employees. This then means that the Labour Inspection Authority on its website creates different risk constructions targeted at different addressees, and that it pays special attention to interrelations between language, risk and "foreign" workers.

The link between "foreign workers", language and safety is not only visible on the Labour Inspection Authority's website but also in a range of documents and initiatives. Many of these are co-authored or co-founded by other stakeholders in the industry. An example of such a cooperation is the brochure "Forstår du hva jeg sier? Krav til språk og kommunikasjon på bygge- og anleggsplassen" [Do you understand what I am saying? Requirements for language and communication in construction sites] (Arbeidstilsynet, 2014) which is co-authored by The Confederation of Norwegian Construction Industries and the three biggest trade unions for construction workers. The brochure provides an overview of all language and communication regulations related to safety and security at work. The brochure addresses the responsibilities of clients, viz. those who order and pay for a construction project, employers and employees. In particular, "foreign" employers and employees are addressed. The first line of the opening paragraph reads: "With many foreign employees and companies in the construction industry lack of communication in the workplace may pose a significant risk." [org. "Med mange utenlandske arbeidstakere og virksomheter i bygge- og anleggsbransjen kan mangel på kommunikasjon på

\footnotetext{
${ }^{4}$ https://www.arbeidstilsynet.no/hms/hms-i-bygg-og-anlegg/ (accessed August 22nd 2018)
} 
REFERENCE: Kraft, Kamilla. 2019. Linguistic securitisation as a governmentality in the neoliberalising welfare state. In: Luisa Martín Rojo and Alfonso Del Percio. Language and Neoliberal Governmentality, 29-48. London/New York: Routledge.

DOI: 10.4324/9780429286711-2

arbeidsplassen utgjøre en betydelig sikkerhetsrisiko.”] (Arbeidstilsynet 2014: 3). Hence, from the beginning, this brochure establishes a connection between the categories "foreign workers", "lack of communication" and "safety risks" (cf. also Author (under review)).

That the brochure is indeed a cooperation between institutions that normally have rather different interests, e.g. worker's rights versus production affordances, attests to a joint understanding of how safety challenges in the industry are connected to language and communication. It could be considered a manifestation of the tradition of negotiation between state, business and labour, and this kind of cooperation is in fact rather visible in the securitisation of the construction industry. Another major initiative called Charter for en skadefri bygge-og anleggsindustri5 [Charter for a construction industry with no injuries] was launched in 2013 and signed by several unions, contractors, the Confederation of Norwegian Construction Industries, and the state as well as one university, charged with conducting research on HESS. The explicit aim of the charter was to create a more safe and secure industry and to decrease fatal accidents. The charter was signed anew in 20176 by all parties, and the new version of the document read: "To avoid injuries it is required that all parties take on responsibility and that we through mutual involvement create a joint effort supported by everyone in the industry. A collaboration for safety and security!" [org. "Det å unngå skader krever både at den enkelte part tar et selvstendig ansvar og at vi gjennom gjensidig involvering skaper en kollektiv innsats fra alle i næringen. Et samarbeid for sikkerhet!']. The discourse is crystal clear: the labour market parties take a joint stance on the importance of safety and security.

Part of the cooperation outlined in the charter is to continually monitor developments in accidents and injuries and to disseminate the results in annual reports. Currently there are three reports that cover 2015, 2016 and 2017. All of these reports, though in different ways, include language and/or communication as reasons for accidents or near-accidents in building sites. The first report, published in 2015, does not mention "language" as a category in itself, rather it mentions "lack of communication" twice, and it does not activate categories such as 'foreign workers'. An example from the report of how lack of communication can lead to accidents is in relation to workers being

\footnotetext{
${ }^{5}$ http://www.bnl.no/globalassets/dokumenter/hms/charter bnl 4sider 3nov-2.pdf (accessed August 22nd 2018) ${ }^{6}$ http://eba.no/globalassets/signert-charter-for-en-skadefri-bygge--og-anleggsnaring.pdf (accessed August 22nd 2018)
} 
REFERENCE: Kraft, Kamilla. 2019. Linguistic securitisation as a governmentality in the neoliberalising welfare state. In: Luisa Martín Rojo and Alfonso Del Percio. Language and Neoliberal Governmentality, 29-48. London/New York: Routledge.

DOI: 10.4324/9780429286711-2

run over by machines. The report concludes that this "is often due to lack of communication between the driver and workers on the ground [...]" [org. "Ofte skyldes dette mangel på kommunikasjon mellom maskinfører og arbeidstakere på bakken [...]” (Arbeidstilsynet, 2015, p. 22). A couple of pages later, "lack of communication between persons and between workers from different companies" [org. "Manglende kommunikasjon mellom personer og mellom arbeidstakere fra ulike virksomheter"] (Arbeidstilsynet, 2015, p. 24) is also mentioned as one of the reasons for accidents. The 2016 and 2017 reports both explicitly mention languages and poor command of "the language" as risk factors. The 2016 report has a section entitled "Communication" where it reads that "Problems with communication [...] may include that one has a poor command of the language, does not wish to communicate for various reasons, and leaders who do not want to communicate." [org. "Problemer med kommunikasjon [...] kan inkludere at man behersker språket dårlig, ikke ønsker å kommunisere av ulike grunner og ledere som ikke ønsker å kommunisere.” (Mostue, Winge, \& Gravseth, 2016, p. 26). Lack of command of "the language" is fronted despite the fact that both reports also identify language and communication as the cause of the fewest number of accidents compared to other causes. The 2017 report specifically emphasises the connection between accidents and foreign workers' lack of command of "the workplace language". Overall, it identifies four factors common in accidents: Age, length of employment with the same employer, language, and employment status (leased or permanent contract with contractor). It also shows how "Norwegian" and "foreign" workers are affected to different degrees by these factors. Interestingly, the report also mentions that due to data limitations it is difficult to assess precisely to what extent language deficits cause accidents (Arbeidstilsynet, 2017, pp. 8, 43).

These reports are authoritative texts that in a longitudinal perspective create expert knowledge about risks and language and which are used to advance specific views on proper behaviour in building sites and for workers. They identify lack of communication as a source of risk, and throughout the reports, lack of communication is constructed not as a general issue among workers, but as one caused by 'foreign' workers in the sites. At the same time, they also construct these workers as more prone to suffer accidents and injuries. While working conditions are also identified as a cause of risk, language figures as an increasingly central explanation, which is interesting as the above-mentioned reports identify language and communication as the least risk-inducing factors. The emphasis on language and communication means that these, without being particularly well defined, can be used as arguments in a powerful discourse on safety and security. In the 
REFERENCE: Kraft, Kamilla. 2019. Linguistic securitisation as a governmentality in the neoliberalising welfare state. In: Luisa Martín Rojo and Alfonso Del Percio. Language and Neoliberal Governmentality, 29-48. London/New York: Routledge.

DOI: $10.4324 / 9780429286711-2$

following, I will turn to how this discourse is brought into and circulated in the actual sites as part of everyday work life and logics.

\subsection{The circulation of discourses on language and securitisation in construction sites}

\subsubsection{Interfaces between securitisation discourses and practices}

The legislation, joint industry initiatives and related studies along with best practice recommendations discussed in the previous section are mediated through various media, notably the industry's news magazine, Byggeindustrien [the Construction Industry]. This is published early every morning and provides an overview of news relevant to the industry. I became aware of the magazine in 2014 as a project leader emailed me a link to a news item from Byggeindustrien about the then recently published Do you understand what I am saying brochure (cf. section 4.1) which outlined language and communication requirements in the construction industry. The project leader asked if I had seen the brochure, hence indicating that he read the daily Byggeindustrien and believed the brochure to be relevant to me. The news magazine is thus one way for the state, unions and employer organisations to disseminate regulations and best-practice recommendations to practitioners.

Another place of circulation is the annual Health, Environment, Safety and Security (HESS) conference. Here, the aforementioned parties meet to discuss developments, challenges and new initiatives within HESS in the industry. Over the years, managers within the HESS area have mentioned these conferences to me, especially highlighting talks by representatives from staffing agencies who provide insights into language and culture challenges when leasing Polish employees. For example, describing how she managed groups of 'Nordic' and 'Polish' workers, a HESS counsellor told me about one such talk which she had found particularly useful. She subsequently sent me the power-point presentation which was based on a newly released research report, commissioned by The Federation of Norwegian Construction Industries and carried out by SINTEF, a research centre specialised in technology and industry research. According to this research report, employers consider "foreign" workers first and foremost a source of flexible staff (Kilskar, Wasilkiewicz, Nygaard, \& Øren, 2017, p. 7). In addition, it is reported that most contractors considered language a central challenge when employing transnational workers. The study also 
REFERENCE: Kraft, Kamilla. 2019. Linguistic securitisation as a governmentality in the neoliberalising welfare state. In: Luisa Martín Rojo and Alfonso Del Percio. Language and Neoliberal Governmentality, 29-48. London/New York: Routledge.

DOI: $10.4324 / 9780429286711-2$

finds that while employers may understand language as a central issue for collaboration, only few consider it a factor in security and safety breaches and risks (Kilskar et al., 2017, p. 7). A major point in the report is that Norwegian and Polish work cultures are different. Put briefly, the report ventures that Norwegians are used to flat structures and independence, whereas Polish workers are used to hierarchical structures and orders (Kilskar et al., 2017, pp. 24, 25, 36). This is also a highly common discourse in the sites where one can frequently encounter the "wall story". Basically, this story is about how Polish workers do not understand inferences: "If you say to a Pole, 'go and have a look at that wall there', then five Poles will go and look at the wall, but that was obviously not what we meant" (fieldnotes June 27, 2014). This is explained as a linguistic problem of not understanding the inference, but also as a cultural problem since Polish workers are depicted as dependent on micromanagement and as showing little ability for self-management. This discourse is rather similar to historical discourses on 'foreign' workers as can be seen from Kulczycki's (1989) study of how Polish workers' attitudes and behaviour were identified as the cause of accidents in the mining industry in the Ruhr area in the late 19th Century, as well as Lahiri's study of Indian seamen serving on British ships from the mid1880's to early 1900's. As Lahiri shows, while these historical stereotypes may be very similar to the ones encountered today, the reasons for difference in behaviour and attitudes were back then not attributed to culture or language, but to differences in the races' cognitive abilities (Lahiri, 2000, p. 159).

In short, securitisation discourses resonate historically and within the actual sites. Furthermore, in the sites they manifest as practices related to HESS.

\subsubsection{Management measures}

Securitisation and the discourse on language and communication as a major risk factor directly affect the management of work processes and workers. Main contractors are legally responsible for organising HESS strategies and rules, and sub-contractors are obligated to follow these. If they do not, they can be sanctioned in different ways, e.g. receiving fines or having to do more frequent internal controls which equals a lot of extra work. In the sites where I did fieldwork, dissemination of safety information, written and oral, to all workers took high priority. Dissemination efforts were typically focused on written safety manuals and oral introduction courses, both directed primarily at 
REFERENCE: Kraft, Kamilla. 2019. Linguistic securitisation as a governmentality in the neoliberalising welfare state. In: Luisa Martín Rojo and Alfonso Del Percio. Language and Neoliberal Governmentality, 29-48. London/New York: Routledge.

DOI: 10.4324/9780429286711-2

new workers in the sites. This fulfilled a legal requirement that all new workers must receive information about safety and security procedures and sign a personal declaration of safety before they start working in a new construction site. When signing the declaration, the worker would attest to having been informed about and having understood safety regulations.

In one site, safety manuals were available in Norwegian, English, Polish and Lithuanian, languages that together represented the majority of speakers in the site. The English, Polish and Lithuanian versions were translations of the Norwegian original. The English translation was rather poor, containing mistakes as well as complicated sentence constructions, which were often due to direct translations of passive structures in the Norwegian text. According to a Polish linguist I asked to help me look at the Polish translation, this text was quite good, though some of the language was rather old-fashioned and complex. In general, the manuals were dense, filled with technical

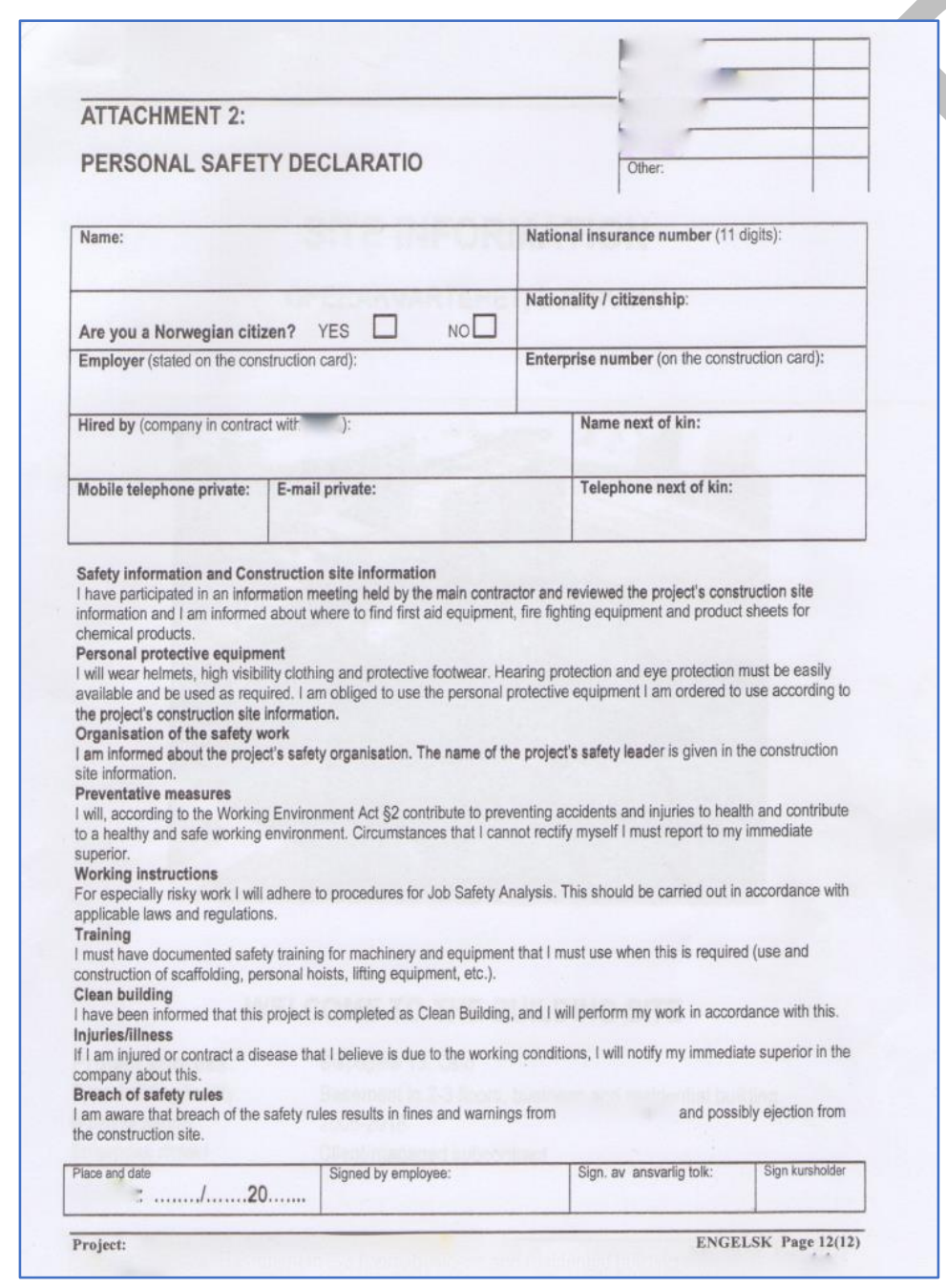

Picture 1 language, showing an orientation towards providing the required safety information and rules of conduct rather than providing easily accessible information. Still, the site management could and did refer to their written multilingual safety information.

Furthermore, this site operated with oral safety courses, obligatory for all who needed to access the construction site. These courses were provided in either English or Norwegian, and if new workers understood neither, the contractors that employed or leased these workers had to provide them with interpreters. The power point slides used for the safety course were with little or no language. This was a deliberate choice made by the course presenters. By minimising written text 
REFERENCE: Kraft, Kamilla. 2019. Linguistic securitisation as a governmentality in the neoliberalising welfare state. In: Luisa Martín Rojo and Alfonso Del Percio. Language and Neoliberal Governmentality, 29-48. London/New York: Routledge.

DOI: 10.4324/9780429286711-2

and instead using a lot of pictures, the opposite strategy of the manuals, their aim was to increase understanding. The importance of ensuring, and documenting, understanding was also visible from the personal safety declarations used in this particular site. As per usual these had to be signed after the oral safety course by new workers, but in addition to standard declarations, interpreters too were obligated to sign and agree that the worker had understood all safety rules (cf. picture 1, fields 'Signed by employee' and 'Sign. av ansvarlig tolk' [Signed by the interpreter responsible]). According to the leader responsible for the course, this feature had been incorporated into the declaration as yet another way to underscore the importance of understanding, and informing about, safety regulations. So, while manuals and declarations were meant to inform workers about safety and security, they also contained a strong element of providing proof, viz. they were material objects providing evidence of the contractors meeting their HESS responsibilities. All of this signifies how safety and language is not a matter taken lightly - and how important it is for contractors to continuously assign responsibility and demonstrate that it has been fulfilled.

In another site, the main contractor had decided that understanding safety and security rules was so important that written safety rules must be in as many languages as required for all to understand them. In addition, all 'foreign' workers must have a Norwegian-speaking contact person. This was reported in Byggeindustrien, the industry's news magazine, as a very high standard for language and safety. The level of interpretation and translation required to fulfil these requirements entailed considerable costs - ultimately to an extent where the cost for interpreters became so high that the main contractor, who had made a public announcement on how they wanted all communication translated and interpreted due to safety concerns, softened the demands for interpretation considerably.

In other sites, contractors relied more on pictures than on written or spoken texts. For them, a useful source of materials was a project that turned HESS regulations into self-explanatory drawings. This project was funded by The Scheme of Regional Safety Representatives with 645,000 NOK (around $70,000 €)$ and its aim was to "reduce accidents and injuries within the industry. To affect attitudes to dangerous work in an easily comprehensible way through good illustrations/drawings of good and bad work situations.” [Org. "Redusere ulykker og skader innen næringen. Påvirke holdninger til 
REFERENCE: Kraft, Kamilla. 2019. Linguistic securitisation as a governmentality in the neoliberalising welfare state. In: Luisa Martín Rojo and Alfonso Del Percio. Language and Neoliberal Governmentality, 29-48. London/New York: Routledge.

DOI: $10.4324 / 9780429286711-2$

risikobetont arbeid på en lettfattelig måte gjennom gode illustrasjoner/ tegninger av gode og dårlige arbeidssituasjoner.']7.

The trend of reducing, rather than translating or interpreting, language was also visible in other sites' HESS information courses which consisted of videos explicating safety routines. A project secretary would show the video to newcomers, who subsequently signed a personal declaration of safety. It was not checked if the workers actually understood the points in the video. Moreover, it is unlikely that the project secretary, not being trained within construction or HESS work, would have been able to answer their questions or concerns. Such safety courses might end up primarily being procedures where a product, e.g. a signed personal declaration, is produced to attest to the proper conduct of the contractor.

Managers also reported that they received aid from Polish-Norwegian-speaking workers to translate Job Safety Analyses, i.e. reports about how a dangerous task is best carried out to minimise risks, and other written materials, so that they could ensure the legal standards. With less important texts, managers might also try to use Polish themselves. A HESS coordinator had produced a sign showing how not to prepare materials for crane-lifting. He showed me the sign (cf. picture 2) and explained how he had tried to accommodate to the linguistic diversity in the site. In Norwegian he had written in a red box: "This is not how we do it! This is strictly prohibited", and then in a separate green box he had written the instructions for how to mount materials properly. The red box

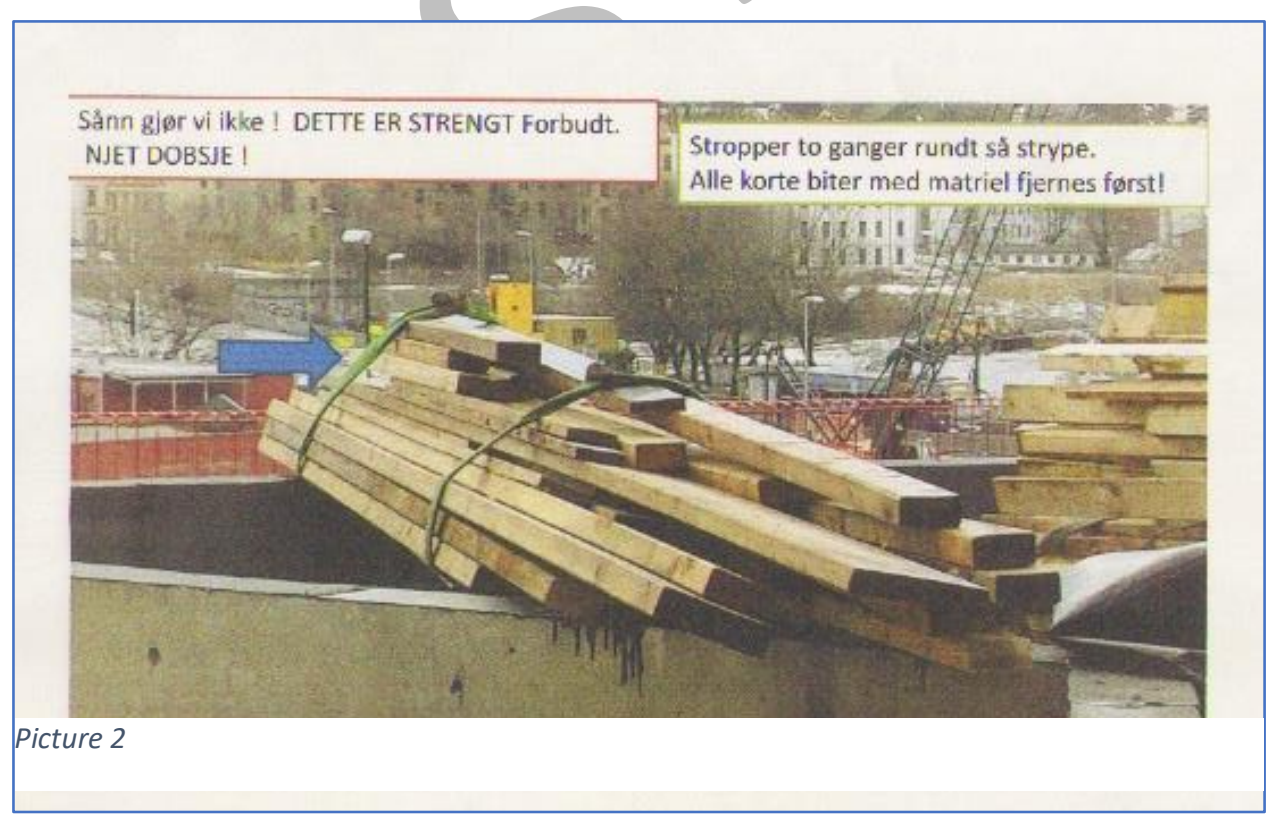
also had a 'Polish' text, "NJET DOBSJE". While this would be recognised by a Polish speaker as meaning "not good" the correct rendering would be "niedobrze". In fact, "njet" is closer to a transliteration of

\footnotetext{
7 https://ba.rvofond.no/visualisering-av-god-hms (accessed August 29 2018)
} 
REFERENCE: Kraft, Kamilla. 2019. Linguistic securitisation as a governmentality in the neoliberalising welfare state. In: Luisa Martín Rojo and Alfonso Del Percio. Language and Neoliberal Governmentality, 29-48. London/New York: Routledge.

DOI: 10.4324/9780429286711-2

Russian "Нer" than Polish "nie". As was also the case with the written manuals, the sign represents little concern with the correct linguistic form. It is therefore questionable who the intended addressees are; the 'foreign' workers or the contractor themselves and their partners.

Arguably, the form and use of safety declarations, manuals and introduction courses indicate that they are not only objects and activities to ensure effective dissemination of safety and security rules, but also function as documentation for the contractors' safety and security routines. In short, they a are also a display of how the contractors take their responsibility seriously.

\subsubsection{Logics about language, safety and 'the other' in daily discourse}

In daily interactions, discourses of language and securitisation also manifest in workers' conversations. These are often versions of 'the wall' story and they have a double narrative: 1) safety and/or efficiency are dependent on language and communication, and 2) language and 'foreign' workers may cause problems.

Below is an excerpt from a meeting between a foreman representing the project's main contractor and two representatives from a surveillance company8. One of the surveillance representatives (SUR) asks for a Health, Environment, Safety and Security (HESS) plan. The foreman (FOR) hands him a map of the site indicating where important points are located, e.g. first-aid stations. This is technically not what SUR asked for, but this is passed without notice. Instead, SUR comments that earlier he saw the employees' HESS representative pick up these maps and had asked him whether he had remembered to translate them into more languages (1l. 2, 3).

01 *FOR: and one $\mathrm{xxx}($ space) $\mathrm{xxx}[$ (cars)]

$02 *$ SUR

[well I saw] that he picked them up (xxx)? so I asked,

03 have you: translated them into more languages?

04 *SUR: ha ha ha ha ha [ha ha]

05 *FOR: [yea:, this is] (0.8) these::, yes [they are in English]

$06 *$ SUR:

[yes here is is], here it is in English.

\footnotetext{
${ }^{8}$ The original conversation was in Swedish and Norwegian. The English text is the author's translation.
} 
REFERENCE: Kraft, Kamilla. 2019. Linguistic securitisation as a governmentality in the neoliberalising welfare state. In: Luisa Martín Rojo and Alfonso Del Percio. Language and Neoliberal Governmentality, 29-48. London/New York: Routledge.

DOI: 10.4324/9780429286711-2

(11. 07-09 omitted)

11 *SUR: because it is of course: (0.4) he thought, that sometimes there are communication

12 problems

13 *FOR: certainly

14 *SUR: and:: (0.4) one (0.6) thing that I at least have noticed is the problem that they $(0.2)$ say yes? (1.1) and then they have not quite erm: (0.2) understood the instructions that have been given

17 *FOR: no

19 *SUR: and then they have carried out the task regardless

20 *SUR: [erh]

21 *FOR: [mm]

$22 *$ SUR: the way that they thought and understood that it must be [done]

23 *FOR:

$[\mathrm{hm}]$

$24 *$ SUR: and then they haven't quite understood the message after all

An immediate observation here is how SUR and FOR pass from the topic of a HESS plan to that of language, emphasising how closely safety and language are connected, at least for SUR. FOR replies to SUR's indirect question about multiple languages (line 3) by looking at the map and stating that it is in English (line 5). SUR quickly aligns with this answer but does not abandon his narrative which he continues in lines 11 and 12. Here, he reframes the question of multiple languages to one of problematic communication, but does not present this as his own observation, or opinion, but rather as that of the aforementioned employee representative. FOR aligns strongly with this claim (1.13) and SUR then pursues this topic in lines 14-16. The interactional caution that SUR exhibits up until this point reflects how the question of language, safety and migrant workers is not uncontested and that a certain measure of agreement needs to be established first. However, after having established joint agreement on the topic, SUR changes footing once again as he presents it as his own observation that "they" do not always quite understand the instructions that they are given. The introduction of the othering category "they" in line 14 is completely unmarked and unquestioned. It is significant that it is never made explicit who "they" refers to, not earlier in the interaction nor later, yet SUR and FOR understand who the referent is regardless. "They" 
REFERENCE: Kraft, Kamilla. 2019. Linguistic securitisation as a governmentality in the neoliberalising welfare state. In: Luisa Martín Rojo and Alfonso Del Percio. Language and Neoliberal Governmentality, 29-48. London/New York: Routledge.

DOI: 10.4324/9780429286711-2

represent a problem because of their lack of understanding combined with their behaviour, i.e. even if they do not quite understand a task, they carry it out regardless. These three turns produce an account that moves from the question of use of multiple languages, presumably in order to ensure understanding, to a statement about communication problems, to an observation about this being caused by "them", which arguably indexes migrant workers. In this way, the responsibility of ensuring understanding moves from the managers who produce the signs to the workers who do not understand them. Moreover, the 'foreign' workers' lack of understanding, according to the above narrative, entails that work is not carried out correctly. In short, language and safety turn into matters of professional skills and language too.

\subsection{Consequences of the language and safety discourses and practices}

Lack of language (i.e. Norwegian or English) and misunderstandings amongst workers in the sites were the reasons reported as to why certain restrictions on communication had been introduced in the various sites and by various contractors. In short, the discourse and practices on language and safety produced and reproduced in both legislation, recommendations and daily conversations do have direct effects. Most contractors had a policy about only offering permanent hire to workers who spoke Norwegian, or another Scandinavian language, or English, simply because they needed to be able to communicate with their permanent staff. Moreover, one main contractor had a policy to hire only Scandinavian-speaking managers on all management levels (cf. Co-Author \& Author 2018). This practice was indeed based on a rationale about ensuring understanding, as the contractor's HESS leader believed that communication would become complicated and opaque if it were to be conducted in English. As he commented, "Norwegian is complicated enough" (interview, June 17, 2014). Being able to ensure understanding is a constant issue for management, part of the reason being their obligation to disseminate safety procedures. The translation of written safety instructions mirrored this concern too. Yet, as the linguistically problematic texts illustrated, contractors aim of informing workers of safety and security regardless of their linguistic backgrounds is conflated with an implicit aim of adhering to legal requirements so as to avoid being sued for misconduct or lose their good reputation.

Another example of restrictions was a site where all radio communication had been limited to Norwegian-only because of minor accidents with materials being lifted by crane. The cause of the 
REFERENCE: Kraft, Kamilla. 2019. Linguistic securitisation as a governmentality in the neoliberalising welfare state. In: Luisa Martín Rojo and Alfonso Del Percio. Language and Neoliberal Governmentality, 29-48. London/New York: Routledge.

DOI: 10.4324/9780429286711-2

accidents had been identified as miscommunication between the Norwegian crane controller and the Polish workers on the ground who used "a combination of Norwegian, German, English and Polish" (fieldnotes, September 29 2014, HESS course). This story was told by an instructor at a HESS introduction course as an explanation of why there were certain language regulations on tasks and training in that particular site. The participants, three Norwegians and one Dane, did not react in any particular way to this story, which seemed to be their general level of participation throughout the course. However, before the course started, and before the Danish participant had arrived, there had been general complaints about how few Norwegians worked in construction these days. This had been a reaction to the teacher's observation that no 'foreign' workers were signed up for the course, which was highly unusual. One of the participants commented, "It is hopeless to be in Norwegian construction sites these days. No one speaks Norwegian", which led another to narrate how he had at some point needed to order a crane, and had reached a Pole, "who spoke neither Norwegian nor English" (fieldnotes, September 29 2014, HESS course). Safety, then, is only one aspect of construction work where language and 'foreign' workers may be activated as problematic. Yet, it is the most consistent one on state, institution, industry and local levels, and it is also the one that can legitimate practices that entail different opportunities for different types of workers, such as language requirements for certain tasks or positions.

\subsection{Concluding remarks}

The regulations and recommendations introduced by powerful state and private institutions, covering employer, employee and government interests, shape a discourse on the interdependence of language and safety with regard to 'foreign' workers. The discourses are backed up by expert knowledge, carried out in collaboration with universities and researchers, though the points that the industry focuses on can be a rather select version of the scholarly findings. The resulting discourses can be seen as technologies of power aimed at disciplining the industry, and in turn the contractors, in order to ensure conditions for safe flexibility in the construction industry. Such a discourse can ultimately also contribute to the legitimisation of employee leasing. Regulations of and recommendations for language as part of a securitisation process (demonstrated in 3.1) are necessary to become part of and be taken seriously in the industry. Moreover, they are necessary for contractors to avoid economic sanctions and getting a bad reputation for not complying with safety standards. 
REFERENCE: Kraft, Kamilla. 2019. Linguistic securitisation as a governmentality in the neoliberalising welfare state. In: Luisa Martín Rojo and Alfonso Del Percio. Language and Neoliberal Governmentality, 29-48. London/New York: Routledge.

DOI: $10.4324 / 9780429286711-2$

The desire to be seen as seriously committed to safety and to avoid sanctions leads contractors to internalise language and safety demands and recommendations: they spend resources - time as well as money - on different strategies and materials that will ensure that the regulations and recommendations for language are followed. They frequently emphasise the need for this as part of HESS work. However, the format and content of especially written materials make it questionable whether creating understanding is the primary purpose or whether their internalisation of these demands leads them to focus more on 'doing being' a serious agent. Moreover, language regulations can at times be bent or softened if they become too economically costly. What is internalised amongst the Norwegian contractors and their managers are then perhaps first and foremost that it is important to show investments into language and securitisation, and that it is important that all legal responsibilities are upheld. This concern is visible from e.g. the practice of having interpreters sign personal safety declarations. In other words, they uphold an idea and discourse on safe flexibility.

While securitisation is evident in the discourses and practices of the contractors, the internalisation of language and securitisation is not limited to managers' language and safety strategies, initiatives and materials. The discourse stated most clearly in the Do you understand what I am saying? brochure about how "foreign workers" often do not understand Norwegian and how this can lead to "lack of communication" and subsequent "safety risks" also permeates everyday conversations between co-workers, signifying a certain strength to the discourse. This is the case even if a substantial amount of reports and research shows that it is very difficult to assess the relationship between language and accidents, or even that this relationship hardly plays any role, at least compared to practices such as short-term employee leasing. Moreover, the daily discourses may actively problematise the 'foreign' or 'Polish' worker due to their lack of language competences and hence lack of understanding. In such interactions, the discourse on language deficits becomes a discourse on professional deficit too because workers without the 'right' language and culture are presented as carrying out work incorrectly, with the consequent understanding that their tasks need to be restricted to something rather simple.

These internalisations - that language and security are deeply entrenched, and that lack of language poses a safety risk and/or a professional deficit - by the Norwegian contractors and their staff mean 
REFERENCE: Kraft, Kamilla. 2019. Linguistic securitisation as a governmentality in the neoliberalising welfare state. In: Luisa Martín Rojo and Alfonso Del Percio. Language and Neoliberal Governmentality, 29-48. London/New York: Routledge.

DOI: 10.4324/9780429286711-2

that certain restrictions on language are implemented in the construction sites. These restrictions entail that workers must accept that they are not likely to get permanent employment if they do not speak Norwegian, or at least English, depending on the contractor. If they do not possess Norwegian or English language skills, their primary value is as a flexible workforce. Some, but relatively few, workers do discipline themselves, i.e. they self-invest in language competences to obtain language skills, hence also accepting that they need to be language workers in addition to workers who are qualified professional builders (cf. Author, under review). Regardless, the majority remains satisfied with their temporary leasing, or at least the promise of stability does not persuade them to pursue language as a road to permanent employment. Internalisation of the securitisation logics with regard to self-management or self-skilling is modest.

The primary impact of disciplinisation and internalisation then lies with the contractors and more broadly the practices of the neoliberalising industry. If the advocates of welfarism cannot stop deregulation of the labour market and employment liberalisation, they can at least control the neoliberalisation. Since most leased workers are migrant workers, regulations on language become an efficient tool. Overtly, the motivation is to protect these workers, as well as their Norwegian coworkers, through language regulations. While everything indicates that quitting leasing would be the most optimal way of ensuring a safe working environment in the industry, this would compromise the industry's business model - having a competitive edge through staff flexibilisation - and hence this form of neoliberal governance seems to be untouchable. What is not untouchable is the safety argument aimed at ensuring the welfare of all, especially in a state where workers' rights remain a central part of the labour market and welfare state. The industry needs to show that it functions according to neoliberal logics of competition, just-in-time production, and profit maximisation, but that it is still safe for all, i.e. it takes care of a basic welfare principle and quiet (some of) the critique of the links between employee leasing, language and safety for workers. A side effect of this truce between neoliberalism and welfarism through securitisation is, however, the limitations on 'foreign' workers' opportunities and value in the workplace.

\section{Literature}

Alsos, K., Bråten, M., \& Trygstad, S. C. (2016). Sjatteringer av likhet: Evaluering av reglene om likebehandling av utleid arbeidskraft (Fafo-rapport). Oslo: Fafo. 
REFERENCE: Kraft, Kamilla. 2019. Linguistic securitisation as a governmentality in the neoliberalising welfare state. In: Luisa Martín Rojo and Alfonso Del Percio. Language and Neoliberal Governmentality, 29-48. London/New York: Routledge.

DOI: 10.4324/9780429286711-2

Arbeidstilsynet. (2012). Arbeidsskader blant utenlandske arbeidstakere (Kompass No. 2).

Trondheim: Arbeidstilsynet.

Arbeidstilsynet. (2014). Forstår du hva jeg sier? Krav til kommunikasjon og språk på bygge- og anleggsplassen (Arbeidstilsynets publikasjoner). Trondheim: Arbeidstilsynet.

Arbeidstilsynet. (2015). Skader i bygg og anlegg: Utvikling og problemområder (Kompass No. 4).

Trondheim: Arbeidstilsynet.

Arbeidstilsynet. (2017). Helseproblemer og ulykker i bygg og anlegg (Kompass No. 1). Trondheim: Arbeidstilsynet.

Bals, J. (2017). Hvem skal bygge landet? Trondheim: Cappelen Damm.

Byggeindustrien. (2014a). Ekstra vanskelig HMS-arbeide i bygg og anlegg. Retrieved from http://www.bygg.no/article/116297

Byggeindustrien. (2014b). Utenlandske arbeidstakere utsettes for større risiko. Retrieved from http://www.bygg.no /article/1194219

Byggeindustrien. (2015). Ingen nedgang i antall dødsulykker. Retrieved from http://www.bygg.no/article/1235316

Charalambous, P., Charalambous, C., \& Rampton, B. (2015). De-securitizing Turkish: Teaching the Language of a Former Enemy, and Intercultural Language Education. Applied Linguistics, 38(6), 800-823. https://doi.org/10.1093/applin/amv063

Esping-Andersen, Gösta. (1990). The three worlds of welfare capitalism. Cambridge: Polity Press. Esping-Andersen, Gosta. (1999). Social Foundations of Postindustrial Economies. Oxford: Oxford University Press.

Fraser, N. (2003). From Discipline to Flexibilization? Rereading Foucault in the Shadow of Globalization. Constellations, 10, 160-171. https://doi.org/10.1111/1467-8675.00321 
REFERENCE: Kraft, Kamilla. 2019. Linguistic securitisation as a governmentality in the neoliberalising welfare state. In: Luisa Martín Rojo and Alfonso Del Percio. Language and Neoliberal Governmentality, 29-48. London/New York: Routledge.

DOI: 10.4324/9780429286711-2

Friberg, J. H. (2016). Arbeidsmigrasjon: Hva vet vi om konsekvensene for norsk arbeidsliv, samfunn og фkonomi? (Fafo-rapport No. 2). Oslo: Fafo. Retrieved from http://www.fafo.no/index.php/zoo-publikasjoner/fafo-rapporter/item/arbeidsmigrasjon Friberg, J. H., \& Eldring, L. (2013). Labour migrants from Central and Eastern Europe in the Nordic countries: Patterns of migration, working conditions and recruitment practices (TemaNord No. 570). Denmark: Norden. Retrieved from http://norden.divaportal.org/smash/get/diva2:702572/FULLTEXT01.pdf

Friberg, J. H., \& Golden, A. (2014). Norges største innvandrergruppe: Historien om migrasjon fra Polen til Norge og om andrespråkskorpuset ASK. NOA Norsk Som Andrespråk, 30, 11-23. Friberg, J. H., \& Haakestad, H. (2015). Arbeidsmigrasjon, makt og styringsideologier: Norsk byggenæring i en brytningstid. Søkelys På Arbeidslivet, 31(3),182-205.

Gallie, D. (2007). Production Regimes and the Quality of Employment in Europe. Annual Review of Sociology, 33(1), 85-104. https://doi.org/10.1146/annurev.soc.33.040406.131724

Goffman, E. (1983). The Interaction Order: American Sociological Association, 1982 Presidential Address. American Sociological Review, 48, 1-17.

Gumperz, J. J., \& Cook-Gumperz, J. (2012). Interactional Sociolinguistics: Perspectives on Intercultural Communication. In C. B. Paulston, S. F. Kiesling, \& E. S. Rangel (Eds.), The Handbook of Intercultural Discourse and Communication (1st ed., pp. 63-76). Oxford: John Wiley \& Sons, Ltd.

Harvey, D. (2005). A brief history of neoliberalism. Oxford: Oxford University Press.

Kilskar, S. S., Wasilkiewicz, K., Nygaard, B., \& Øren, A. (2017). Flerkulturelle arbeidsplasser $i$ byggenaringen: Kartlegging av muligheter og utfordringer (No. 2017:00352). Trondheim: SINTEF.

Kotler, P. (2003). Marketing Management (11th ed.). New Jersey: Pearson Education International. 
REFERENCE: Kraft, Kamilla. 2019. Linguistic securitisation as a governmentality in the neoliberalising welfare state. In: Luisa Martín Rojo and Alfonso Del Percio. Language and Neoliberal Governmentality, 29-48. London/New York: Routledge.

DOI: 10.4324/9780429286711-2

Kress, G., \& Van Leeuwen, T. (2001). Multimodal discourse, the modes and media of contemporary communication. London: Arnold.

Kulczycki, J. J. (1989). ‘Scapegoating' the Foreign Worker: Job Turnover, Accidents, and Diseases among Polish Coal Miners in the German Ruhr. Polish American Studies, 46, 42-60.

Lahiri, S. (2000). Patterns of Resistance: Indian Seamen in Imperial Britain. In A. J. Kershen (Ed.), Language, Labour and Migration. Aldershot: Ashgate.

Lazaridis, G., \& Wadia, K. (2015). Introduction. In G. Lazaridis \& K. Wadia, The Securitisation of Migration in the EU: Debates Since 9/11. London: Palgrave Macmillan Limited.

Mostue, B. A., Winge, S., \& Gravseth, H. M. (2016). Ulykker i bygg og anlegg i 2015 (Kompass No. 8) (p. 46). Trondheim: Arbeidstilsynet.

NHO. (2016). Bemanningsbarometeret 2016: Bemanningsbransjens årsstatistikk. NHO Service/Prognosesenteret.

Ødegård, A. M., \& Andersen, R. K. (2011). Østeuropeisk arbeidskraft i hotell, verft, fiskeindustri og kjфttindustri (Fafo-notat No. 21). Oslo: Fafo.

Peck, J., Theodore, N., \& Ward, K. (2005). Constructing markets for temporary labour: employment liberalization and the internationalization of the staffing industry. Global Networks, 5, 3-26.

Prestegård, S. (2015, November 18). Ap: Ingen skal dø på jobben. Dagsavisen. Retrieved from https://www.dagsavisen.no/oslo/ap-ingen-skal-do-pa-jobben-1.458601

Rampton, B. (2014). Gumperz and governmentality in the 21st century: Interaction, power and subjectivity. Working Papers in Urban Language \& Literacies, 136.

Rose, N., O’Malley, P., \& Valverde, M. (2006). Governmentality. Annual Review of Law and Social Science, 2, 83-104. 
REFERENCE: Kraft, Kamilla. 2019. Linguistic securitisation as a governmentality in the neoliberalising welfare state. In: Luisa Martín Rojo and Alfonso Del Percio. Language and Neoliberal Governmentality, 29-48. London/New York: Routledge.

DOI: 10.4324/9780429286711-2

Sennett, R. (1998). The corrosion of character: the personal consequences of work in the new capitalism. New York: W.W. Norton.

Skovholt, K., \& Veum, A. (2014). Tekstanalyse: Ei innføring. Livonia: Cappelen Damm Akademisk.

Torfing, J. (2009). Fra welfare til workfare: Nye udfordringer til velfærdsprofessionerne. Gjallerhorn, 10, 6-12.

Willig, R. (2009). Self-Realization Options: Contemporary Marching Order in the Pursuit of Recognition. Acta Sociologica, 52, 350-364. http://10.2307/25652144

Author, under review

Co-author \& Author, 2018 